\title{
EFFECT OF CONJUGATED EQUINE ESTROGENS AND TAMOXIFEN ADMINISTRATION ON THYROID GLAND HISTOMORPHOLOGY OF THE RAT
}

Luiz Felipe Bittencourt de Araujo, José Maria Soares Jr, Ricardo Santos Simões, Pedro Luiz Calió, Ricardo Martins Oliveira-Filho, Manuel de Jesus Simões, Mauro Abi Haidar, Edmund C. Baracat

\begin{abstract}
Araujo LFB, Soares Jr JM, Simões RS, Calió PL, Oliveira-Filho RM, Simões MJ, Haidar MA, Baracat EC. Effect of conjugated equine estrogens and tamoxifen administration on thyroid gland histomorphology of the rat. Clinics. 2006;61(4):321-26.
\end{abstract}

OBJECTIVE: The aim of this study was to evaluate the action of the conjugated equine estrogens and tamoxifen on the morphology of thyroid gland in ovariectomized (OVx) rats.

METHODS: Conjugated equine estrogens (CEE), clinically used as estrogen therapy, is a complex formulation containing multiple estrogens that decrease menopausal symptoms. Thirty ovariectomized rats were randomly divided into 3 treatment groups: GI, vehicle (propylene glycol); GII, CEE $200 \mu \mathrm{g} / \mathrm{kg}$ per day; and GIII, tamoxifen $1 \mathrm{mg} / \mathrm{kg}$ per day. Another group of 10 rats with intact ovaries (GIV) was included, treated with the vehicle, and sacrificed during estrous. All animals were treated by gavage for 50 days, after which they were sacrificed. Blood samples were collected, and the thyroid was removed for morphological analysis and PCNA evaluation through immunohistochemical study.

RESULTS: The thyroid follicular cell height was increased in animals treated with CEE $(14.90 \pm 0.20 \mu \mathrm{m})$, with TAM $(14.90 \pm$ $0.10 \mu \mathrm{m})$, and in rats with intact ovaries $(15.10 \pm 0.50 \mu \mathrm{m})$ in comparison to that of the vehicle group $(9.90 \pm 0.20 \mu \mathrm{m})(P<0.001)$. The follicular area was larger in the CEE $\left(2,225 \pm 51 \mu \mathrm{m}^{2}\right)$ and TAM $\left(2,127 \pm 67 \mu \mathrm{m}^{2}\right)$ groups compared to that of the vehicle group $\left(5,016 \pm 53 \mu \mathrm{m}^{2}\right)$. The levels of T4 and T3 in rats treated with CEE, with Tamoxifen and in rats with intact ovaries, were higher than those those in the vehicle group $(P<0.001)$. The PCNA index in the vehicle group was lower than in other groups. CONCLUSION: Our data suggest that estrogen and tamoxifen administration has a proliferative effect on the thyroid.

KEYWORDS: Estrogen. Tamoxifen. Thyroid. Ovariectomized rats, Morphometrics.

\section{INTRODUCTION}

There is a great wealth of published data on the value of estrogen therapy in alleviating menopausal symptoms, such as hot flashes and insomnia, and in preventing chronic problems, including urogenital atrophy and osteoporosis. ${ }^{1,2}$. Although some studies have demonstrated influences of

Department of Obstetrics and Gynecology, University of São Paulo Medical School, São Paulo, Brazil. Department of Ginecology, Federal University os São Paulo, São Paulo, Brazil.

Email: jsoares415@hotmail.com

Received for publication on January 27, 2006

Accepted for publication on March 28, 2006 estrogens on the development, physiology, and pathology of the thyroid gland, questions about the effects of estrogen replacement therapy on the thyroid gland remain unanswered $^{3,6}$. Additionally, thyroid diseases are more common in women. ${ }^{7}$ Conjugated equine estrogens (CEE), clinically used as estrogen therapy, is a complex formulation (obtained from pregnant mares' urine) containing multiple estrogens, including several not secreted by human ovaries, as well as other biologically active steroids. These hormones stimulate the proliferation of tissue with estrogen receptors. ${ }^{8}$

Hypothyroid women who are under treatment with thyroxine (T4) are reported to experience changes in the circulating levels of T4 and TSH upon starting estrogen re- 
placement therapy. In fact, under these conditions, there are increased titers of thyroxine-binding globulin leading to an enhanced fraction of bound thyroxine and, consequently, a feedback-driven increase of TSH levels. Since the adaptation is somewhat insufficient, there is an increased need for thyroxine in these women taking hormone replacement therapy. ${ }^{4}$

In addition, some experimental studies have shown that estrogens might up-regulate their own receptors in the thyroid and thereby influence the growth of the gland and the proliferation of thyrocytes. ${ }^{5,9}$

Tamoxifen is a selective estrogen receptor modulator (SERM) with either estrogen agonistic or antagonistic activities, depending upon the particular target organ. It is a valuable therapeutic agent, with applications in the treatment and prevention of estrogen-responsive breast cancer. ${ }^{10}$ The efficacy of tamoxifen in preventing recurrence and fatalities from breast cancer when used as an adjuvant treatment has been well-established. ${ }^{10}$ Additionally, the recent introduction of SERMs may further increase the safety of hormone replacement therapy, but the effects of these drugs on the thyroid gland morphology are not fully understood. Therefore, the aim of this study was to study the effects of tamoxifen and estrogens on thyroid gland morphology of ovariectomized rats.

\section{METHOD}

All procedures involving rats were approved by the Federal University of São Paulo Research Ethics Committee; animal handling conformed to the APS Guiding Principles for The Care and Use of Animals. Adult female (3 months) Wistar rats (180-210 g body weight) were kept under a 14:10 h light:dark cycle (lights on at 08:00 am) at $23^{\circ} \mathrm{C}$ and were fed a standard diet and tap water ad libitum. Thirty animals were bilaterally ovariectomized (OVx). One month later, the rats were randomly divided into 3 treatment groups: GI, vehicle (propylene glycol); GII, conjugated equine estrogens (CEE) $200 \mu \mathrm{g} / \mathrm{kg}$ per day; and GIII, tamoxifen $1 \mathrm{mg} / \mathrm{kg}$ per day. Another group of 10 rats with intact ovaries and treated with vehicle (GIV) was included from which vaginal smears were daily collected for identifying the phase of estrous cycle. All animals were treated once a day by oral route (gavage) for 50 consecutive days. Then, the rats were weighed and sacrificed by decapitation, trunk blood was collected and centrifuged. Serum was separated and stored at $-20^{\circ} \mathrm{C}$ until assay for hormone level determinations. The animals in GIV were sacrificed only during estrous. Thyroid glands were carefully dissected out, weighed, and immediately fixed in Bouin's solution for 24 hours. Every fixed gland was dehydrated in graded alco- hol, embedded in paraffin, sectioned at $4 \mu \mathrm{m}$, and stained with hematoxylin and eosin for light microscopic analysis. A section of the central portion of every lobe was selected for analysis. ${ }^{11}$ For determination of the thyroid follicular cell proliferation index, the sections were immunohistochemically stained with anti-proliferating cell nuclear antigen (PCNA) antibody PC-10 (Dako, Denmark). The PCNA-positive nuclei (PCNA-labeling index) in 1,000 cells of the follicular epithelium were counted and expressed as percentages of the total cell count.

Serum triiodothyronine (T3), thyroxine (T4), and thyroid stimulating hormone $(\mathrm{TSH})$ were measured with radioimmunoassay kits, using respectively Coat-A-Count ${ }^{\circledR}$ Canine T3 Kit (Diagnostic Products Co., CA), DPC Total T4 Kit (Diagnostic Products Co., CA), and Rat Thyroid Stimulating Hormone (rTSH) $\left[{ }^{125} \mathrm{I}\right]$ assay system (Amersham Pharmacia Biotech, UK), respectively. Coefficients of variation for the TSH assays were 9.6\% within assay and $4.9 \%$ between assays. This assay system has been used and validated in other experimental studies. ${ }^{12-14}$

The morphometric measurements were performed using digitalized images obtained directly from the light microscope via a video camera and stored on magnetic media. Measurements were automatically processed using Imagelab Softium ${ }^{\circledR}$ software (São Paulo, Brazil). For each sample, the areas (follicular and colloidal) from 200 follicles and the height of 4 cells per follicle (400 per sample) were measured at a magnification of 400x. Two different observers independently evaluated the images, with similar resutls. Both of them were blind to the analyzed groups.

\section{Statistical analysis}

Data from morphometry and hormone level determinations are given as mean \pm standard error of the mean (SEM); the results were analyzed using 1-way ANOVA followed by the Newmann-Keuls multiple comparison test, with the level of significance set at $P<0.05$.

\section{RESULTS}

Under light microscopy, in the control ovariectomized group (GI, treated with propylene glycol), the thyroid gland had a thin connective tissue capsule around it. Also, fine septa emerging from the capsule divided the gland into numerous small ill-defined lobules with large and distended follicles, which in turn were often lined by cuboidal epithelium. The colloid deposited therein appeared heavily stained and often filled up the entire lumen without conspicuous peripheral vacuoles (Fig. 1). The luminal surface of the follicular cells was flattened. In addition, each fol- 
licle was surrounded by a delicate network of reticular fibres and blood capillaries.

Clear-cut differences in thyroid gland structure were noticed between the hormone-treated groups (conjugated equine estrogens and tamoxifen, GII and GIII, respectively) and the ovariectomized control group (GI). The connective tissue capsule around the thyroid gland in GII (conjugated equine estrogens) and in GIII (tamoxifen) was thicker than in GI (ovariectomized rat). Also, the lobules presented small and partially collapsed follicles with a reduction in the amount of colloid in GII (conjugated equine estrogens), in GIII (tamoxifen), and in GIV (rats with intact ovaries) as compared to the amount in GI (ovariectomized rats). Additionally, the follicular epithelium was seen to be columnar with larger nuclei in GII (estrogen treatment), in GIII (tamoxifen treatment), and in GIV (with intact ovaries) than in GI (ovariectomized rats, Fig. 1). The reticular fibers and blood capillaries in GII (conjugated equine estrogens) and in GIII (tamoxifen) were more developed than in GI (ovariectomized), but not compared to those in GIV (rats with intact ovaries).

The thyroid weight in GI (ovariectomized rats treated with vehicle) was lower than in other groups (Table 1). The morphometric analysis showed that the follicular cell heights in GII (estrogen treatment), in GIII (tamoxifen treatment), and GIV (with intact ovaries) were higher than in GI $(\mathrm{P}<0.001)$, and the measurements in GII (estrogen treatment) produced values that were essentially indistinguishable from those in GIII (tamoxifen treatment) and in GIV (with intact ovaries) (Table 1). Also, the follicular and colloid areas of GII (estrogen treatment) and of GIII (tamoxifen treatment) were smaller than those of GI (ovariectomized rats treated with vehicle) $(\mathrm{P}<0.001)$, but not significantly different from each other in this regard. Additionally, the PCNA index in GI (ovariectomized rats with vehicle) was lower than in other groups (Fig. 2).

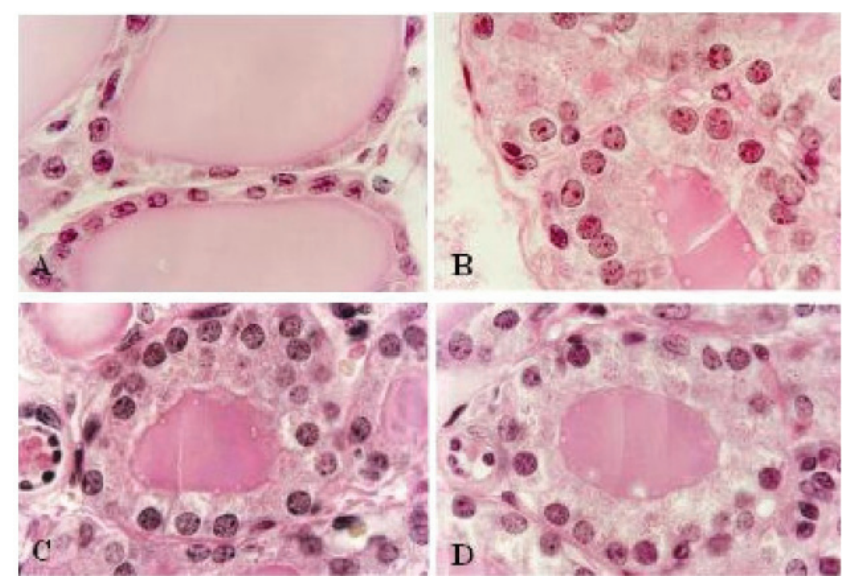

Figure 1- Photomicrograph of the central area of the right thyroid lobe of ovariectomized rats: A. the follicular epithelium is cuboidal with small nuclei (GI); B. the follicular epithelium is columnar epithelium with large nuclei (GII); C. the follicular epithelium is columnar epithelium with large nuclei (GIII); D. the follicular epithelium is columnar epithelium with large nuclei (GIV) (HE, x 1100).

The levels of TSH in GII (estrogen treatment), in GIII (tamoxifen treatment), and in GIV (intact ovaries) were lower than those in GI (ovariectomized rats treated with vehicle, $P<0.001$, Table 1). The levels of T3 and T4 in GII (estrogen treatment), in GIII (tamoxifen treatment), and in GIV (intact ovaries) were higher than those in GI (ovariectomized rats treated with vehicle, $P<0.001$, Table 1).

\section{DISCUSSION}

Tamoxifen is a triphenylethylene derivative commonly used in the treatment of breast cancer. ${ }^{15-18}$ This drug is known to have various biological effects ranging from complete estrogen antagonism to pure estrogen agonism, depending upon its concentration, the sex of the animal, and the target organ..$^{15,19,20}$

Table 1- Morphological and functional thyroid data of adult ovariectomized rats treated for 50 days with conjugated equine estrogens (GII), tamoxifen (GIII), or drug vehicle (GI). (mean \pm SEM)

\begin{tabular}{|c|c|c|c|c|}
\hline Treatments & GI (vehicle) $(\mathrm{n}=10)$ & GII $($ estrogen $)(n=10)$ & GIII $($ tamoxifen $)(\mathrm{n}=10)$ & GIV (estrous)** $(\mathrm{n}=10)$ \\
\hline Body weight (g) & $270.50 \pm 4.90$ & $226.70 \pm 4.30^{\mathrm{a}}$ & $217.50 \pm 5.10^{\mathrm{a}}$ & $228.00 \pm 3.70^{\mathrm{a}}$ \\
\hline Thyroid weight (g) & $10.80 \pm 0.60$ & $18.80 \pm 1.50^{\mathrm{a}}$ & $16.10 \pm 1.70^{\mathrm{a}}$ & $15.60 \pm 1.60^{\mathrm{a}}$ \\
\hline $\mathrm{T} / \mathrm{B}$ & $3.98 \pm 0.23$ & $8.28 \pm 0.66^{\mathrm{a}}$ & $7.39 \pm 0,78^{b}$ & $6.84 \pm 0.69^{\mathrm{c}}$ \\
\hline Cell height $(\mu \mathrm{m})$ & $9.90 \pm 0.20$ & $14.9 \pm 0.20^{\mathrm{a}}$ & $14.9 \pm 0.10^{\mathrm{a}}$ & $15.1 \pm 0.50$ \\
\hline Follicular area $\left(\mu \mathrm{m}^{2}\right)$ & $5.016 \pm 53$ & $2.225 \pm 5^{\mathrm{a}}$ & $2.127 \pm 67^{\mathrm{a}}$ & $3.112 \pm 41$ \\
\hline Colloid area $\left(\mu \mathrm{m}^{2}\right)$ & $4.328 .10 \pm 174.90$ & $1.303 .90 \pm 64.90^{\mathrm{a}}$ & $1.325 .20 \pm 86.10^{\mathrm{a}}$ & $1.404 .00 \pm 78.40^{\mathrm{a}}$ \\
\hline PCNA & $0.014 \pm 0.006$ & $0.086 \pm 0.013^{\mathrm{a}}$ & $0.098 \pm 0.01^{\mathrm{a}}$ & $0.096 \pm 0.008^{\mathrm{a}}$ \\
\hline \multicolumn{5}{|l|}{ Hormonal analyses* } \\
\hline TSH (ng/mL) & $6.65 \pm 0.17$ & $4.09 \pm 0.15^{\mathrm{a}}$ & $3.92 \pm 0.23^{\mathrm{a}}$ & $3.42 \pm 0.15^{\mathrm{a}}$ \\
\hline T3 (ng/mL) & $1.44 \pm 0.05$ & $1.90 \pm 0.06^{\mathrm{b}}$ & $2.01 \pm 0.08^{\mathrm{a}}$ & $2.22 \pm 0.15^{\mathrm{a}}$ \\
\hline $\mathrm{T} 4(\mu \mathrm{g} / \mathrm{mL})$ & $3.11 \pm 0.08$ & $7.46 \pm 0.45^{\mathrm{a}}$ & $8.47 \pm 0.47^{\mathrm{a}}$ & $8.65 \pm 0.32^{\mathrm{a}}$ \\
\hline
\end{tabular}

$\mathrm{T} / \mathrm{B}=$ thyroid weight/body weight ratio $\mathrm{x} 10^{5} ;{ }^{\mathrm{a}} P<0.001$ compared to GI; ${ }^{\mathrm{b}} P<0.01$ compared to $\mathrm{GI} ;{ }^{\mathrm{c}} P<0.05$ compared to GI; $\mathrm{n}=$ number of animals. *the means of 3 assays; **non-ovariectomized control, treated with vehicle, sacrificed during estrous 


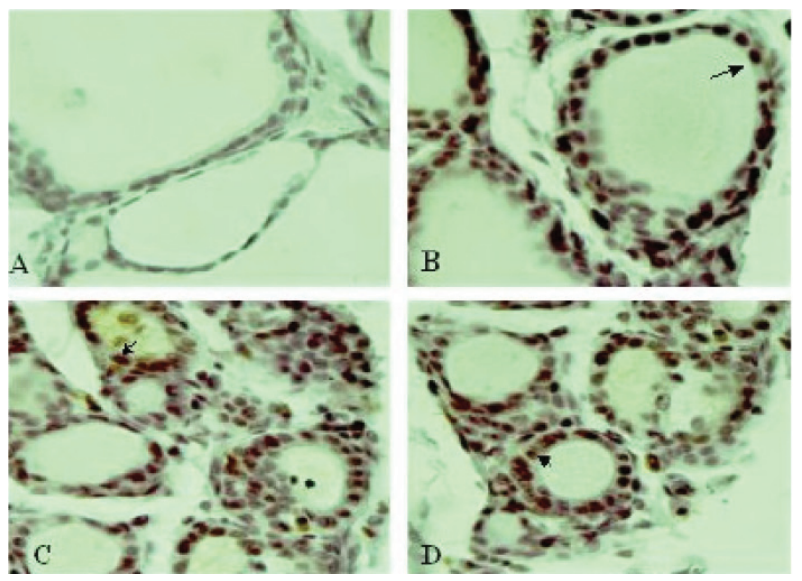

Figure 2- Photomicrograph of PCNA reaction in the central area of the right thyroid lobe of ovariectomized rats: A. ovariectomized animals treated with vehicle (GI); B. ovariectomized animals treated with conjugated equine estrogens (GII); C. ovariectomized animals treated with tamoxifen (GIII); D. animals in estrous phase treated with vehicle (GIV). The arrows show the positive reaction. (HE, x 1100).

In humans and rats, tamoxifen is predominantly antiestrogenic with residual estrogenic activities, ${ }^{15}$ except in the uterus ${ }^{21}$ and thyroid gland, as demonstrated in this study.

In fact, the results of the present investigation showed that the thyroid gland was significantly affected by treatment with estrogen or tamoxifen, showing an increased follicular cell height and decreased follicular and colloidal areas as compared to controls. Also, the PCNA index was increased in treated groups compared to the vehicletreated group. These histological features were generally correlated to the thyroidal functional status, ${ }^{22}$ since the serum T3 and T4 levels were enhanced in animals treated with estrogen or tamoxifen as compared to the vehicletreated controls.

The effects of estrogens and tamoxifen on thyroid gland have been the subject of many investigations, but several aspects of these effects are still unknown. The presence of estrogen receptors in the thyroid suggests a direct action of estrogens and estrogenic-stimulating drugs on the gland..$^{23-25}$ Also, some experiments using thyrocytes in vitro have demonstrated that estrogen has a definite role in the proliferation of these cells. . $, 6,26,27$

However, some studies have shown that the effects of estrogen and tamoxifen on thyroid gland may be rather indirect, as a consequence of increased serum levels of thyroxine-binding globulin (TBG) and the associated changes in thyroid function. ${ }^{28-31}$ Other data suggests that the action of these drugs may be directly on the pituitary through the release of TSH. ${ }^{32-35}$ Donda et $\mathrm{al}^{13}$ showed that estrogen had a stimulatory effect on pituitary function and release of TSH. However, in our study, an increase in TSH levels was detected after oophorectomy compared to that in the estrous phase and treated groups. One explanation may be the negative feedback of T3 and T4 hormones on TSH release after the hormonal treatment. ${ }^{36}$ In addition, another study showed that estrogen may interact with TSH and thus play a role in thyroid function; conversely, sex steroids may in turn modulate TSH-induced cell proliferation. ${ }^{37}$

As a matter of fact, estradiol administration to female rats is able to reduce the TSH levels. ${ }^{33}$ Also, another report using pituitary cells in vitro suggested that estradiol was physiologically important in maintaining normal responses to thyrotropin-releasing hormone (TRH) in female rats. ${ }^{38}$

Regardless of the mechanism, our data suggest that tamoxifen may be an agonist to estrogen receptors in the rat thyroid leading to proliferation of thyrocytes and increasing T3 and T4 levels. Although the extrapolation of these results to humans should be interpreted with caution, it is highly conceivable that the monitoring of thyroid function may be important for those patients who are or are going to be under estrogen or tamoxifen therapy.

\section{RESUMO}

Araujo LFB, Soares Jr JM, Simões RS, Calió PL, OliveiraFilho RM, Simões MJ, Haidar MA, Baracat EC. Os efeitos dos estrogênios conjugados equinos e do tamoxifeno na histomorfologia da glândula tireóide de ratas. Clinics. 2006;61(4):321-26.

OBJETIVO: Avaliar a ação dos estrogênios conjugados eqüinos e do tamoxifeno na histomorfologia da tireóide de ratas.

MÉTODO: Estrogênios conjugados eqüinos são ministrados clinicamente como terapia estrogênica e contêm formulação complexa com muitos tipos de estrogênios que diminuem os sintomas da pós-menopausa. Trinta ratas adultas ooforectomizadas foram divididas aleatoriamente em três grupos: GI - veículo (propilenoglicol); GII - ECE $200 \mu \mathrm{g} /$ Kg por dia; e GIII - TAM $1 \mathrm{mg} / \mathrm{Kg}$ por dia. Acrescentou-se ainda um grupo de 10 animais com os ovários intactos e tratados com veículo (GIV). Todos os animais foram tratados por gavagem durante 50 dias consecutivos, ao final foram coletadas amostras do sangue e a tireóide removida e processada para análise morfológica e imunohistoquímico para avaliar o PCNA. 
RESULTADOS: A maior altura das células foliculares foi observada nos animais tratados com ECE $(14,90 \pm 0,20$ $\mu \mathrm{m})$, TAM $(14,90 \pm 0,10 \mu \mathrm{m})$ e no grupo com ovários intactos $(15,10 \pm 0,50 \mu \mathrm{m})$, comparando-se aos controles ovariectomizados $(\mathrm{GI})(9,90 \pm 0,20 \mu \mathrm{m})(\mathrm{p}<0,001)$. A maior área folicular foi detectada nos grupos tratados com ECE $\left(2.225 \pm 51 \mu \mathrm{m}^{2}\right)$ e com TAM $\left(2.127 \pm 67 \mu \mathrm{m}^{2}\right)$, comparado ao veículo $\left(5.016 \pm 53 \mu \mathrm{m}^{2}\right)$ em animais ooforectomizados. Os níveis de T4 e T3 nos grupos tratados com ECE, com TAM e no grupo com ovários intactos foram maiores do que no grupo tratado com veículo $(\mathrm{p}<0,001)$. O índice do PCNA no grupo tratado com veículo foi menor do que em todos os outros grupos.

CONCLUSÃO: Nossos dados sugerem que a administração de ECE e TAM resulta em atividade proliferativa na tireóide.

UNITERMOS: Estrogênio. Tamoxifeno. Tireóide. Ratas, Morfologia.

\section{REFERENCES}

1. Deady J. Clinical monograph: hormone replacement therapy. J Manag Care. Pharm. 2004;10:33-47.

2. Hendrix SL. Long-term use of hormone therapy for urogenital complaints: is there a role? Med Clin North Am. 2003;87:1029-37.

3. Kawabata W, Suzuki T, Moriya T, Fujimori K, Naganuma H, Inoue S, et al. Estrogen receptors (alpha and beta) and 17beta-hydroxysteroid dehydrogenase type 1 and 2 in thyroid disorders: possible in situ estrogen synthesis and actions. Mod Pathol. 2003;16:437-44.

4. Schindler AE. Thyroid function and postmenopause. Gynecol Endocrinol. 2003;17:79-85.

5. Banu SK, Govindarajulu P, Aruldhas MM. Developmental profiles of $\mathrm{TSH}$, sex steroids, and their receptors in the thyroid and their relevance to thyroid growth in immature rats. Steroids. 2002;67:137-44.

6. Banu SK, Arosh JA, Govindarajulu P, Aruldhas MM. Testosterone and estradiol differentially regulate thyroid growth in Wistar rats from immature to adult age. Endocr Res. 2001;27:447-63.

7. Hollowell JG, Staehling NW, Flanders WD, Hannon WH, Gunter EW, Spencer CA, et al. Serum TSH, T (4), and thyroid antibodies in the United States population (1988 to 1994): National Health and Nutrition Examination Survey (NHANES III). J Clin Endocrinol Metab. 2002;87:489-99.

8. Baracat EC, Simoes MJ, Soares JM Jr, Haidar MA, Rodrigues de Lima G. Ultrastructural aspects of the postmenopausal endometrium after oral or transdermal estrogen administration. Clin Exp Obstet Gynecol. 2001;28:26-30.

9. Manole D, Schildknecht B, Gosnell B, Adams E, Derwahl M. Estrogen promotes growth of human thyroid tumor cells by different molecular mechanisms. J Clin Endoc Metabol. 2001;86:1072-7.

10. EBCTCG. Systemic treatment of early breast cancer by hormonal, cytotoxic, or immune therapy. Lancet. 1992;339:1-15.

11. Denef JF, Cordier AC, Mesquita M, Haumont S. The influence of fixation procedure, embedding medium and section thickness on morphometric data in the thyroid. Histochemistry. 1979;63:163-71.
12. Ikeda T, Nishikawa A, Son HY, Nakamura H, Miyauchi M, Imazawa T, et al. Synergistic effects of high-dose soybean intake with iodine deficiency, but not sulfadimethoxine or phenobarbital, on rat thyroid proliferation. Jpn J Cancer Res. 2001;92:390-5.

13. Donda A, Reymond F, Rey F, Lemarchand-Beraud T. Sex steroids modulate the pituitary parameters involved in the regulation of TSH secretion in the rat. Acta Endocrinol (Copenh). 1990;122:577-84.

14. Ishikawa J, Fuse Y, Wakabayashi K. Choice of extraction procedure for estimation of anterior pituitary hormone content. Endocrinol Jpn. $1987 ; 34: 755-67$

15. Jordan VC. Alternate antiestrogens and approaches to the prevention of breast cancer. J Cell Biochem. 1995;22:51-7.

16. Pyrhonen S, Ellmen J, Vuorinen J, Gershanovich M, Tominaga T, Kaufmann M, et al. Meta-analysis of trials comparing toremifene with tamoxifen and factors predicting outcome of antiestrogen therapy in postmenopausal women with breast cancer. Breast Cancer Res Treat. 1999;56:133-43.

17. Mortimer JE, Boucher L, Baty J, Knapp DL, Ryan E, Rowland JH. Effect of tamoxifen on sexual functioning in patients with breast cancer. J Clin Oncol. 1999;17:1488-92.

18. Nayfield SG. Tamoxifen's role in chemoprevention of breast cancer: an update. J Cell Biochem. 1995;22:42-50.

19. MacNab MW, Tallarida RJ, Joseph R. An evaluation of tamoxifen as a partial agonist by classical receptor theory-an explanation of the dual action of tamoxifen. Eur J Pharmacol. 1984;103:321-6.

20. Wade GN, Powers JB. Tamoxifen antagonizes the effects of estradiol on energy balance and estrous behavior in Syrian hamsters. Am J Physiol Cell Physiol. 1993;265:R559-62.

21. Andrade PM, Silva ID, Borra RC, Lima GR, Baracat EC. Estrogen and selective estrogen receptor modulator regulation of insulin-like growth factor binding protein 5 in the rat uterus. Gynecol Endocrinol. 2002;16:265-70

22. Heimann P. Ultrastructure of the human thyroid. Acta Endocrinol (Copenh). 1966;53:1-102. 
23. Chaudhuri PK, Patel N, Sandberg L, Prinz RA. Distribution and characterization of steroid hormone receptors in human thyroid tissue. World J Surg. 1986;10:737.

24. Giani C, Campani D, De Negri F, Martini L, Fabbri R, Bonacci R. Interference of thyroperoxidase on immuno-cytochemical determination of steroid receptors in thyroid tissue. J Endocrinol Invest. 1993;16:3743.

25. Zayed I, Esch E, Mcconnell RF. Systemic and histopathologic changes in Beagle dogs after chronic daily oral administration of synthetic (ethinylestradiol) or natural (estradiol) estrogens, with special reference to the kidney and thyroid. Toxicol Pathol. 1998;26:730-41.

26. Banu KS, Aruldhas MM. Sex steroids regulate TSH-induced thyroid growth during sexual maturation in Wistar rats. Exp Clin Endocrinol. 2002;110:37-42.

27. MacNab MW, Tallarida RJ, Joseph R. Effect of glucocorticoids and oestrogen on interleukin- 6 production by human thyrocytes from patients with Graves' disease and toxic multinodular goitre and from HTori3 cells. Eur J Endocrinol. 1997;137:429-32.

28. Zidan J, Rubenstein W. Effect of adjuvant tamoxifen therapy on thyroid function in postmenopausal women with breast cancer. Oncology. 1999;56:43-5.

29. Oppenheimer JH. Role of plasma proteins in binding distribution, and metabolism of the thyroid hormones. N Engl J Med. 1968;278:1153-62.

30. Ain KB, Mori Y, Refetoff S. Reduced clearance rate of thyroxinebinding globulin (TBG) with increased sialylation: a mechanism for estrogen-induced elevation of serum TBG concentration. J Clin Endocrinol. 1987;65:689-96.
31. Bottiglioni F, de Aloysio D, Nicoletti G, Mauloni M, Mantuano R, Capelli M. A study of thyroid function in the pre- and post-menopause. Maturitas. 1983;5:105-114.

32. Watanobe H, Takebe K. Role of postnatal gonadal function in the determination of thyrotropin (TSH) releasing hormone-induced TSH response in adult male and female rats. Endocrinology. 1987;120:17118.

33. Boado R, Ulloa E, Zaninovich AA. Effects of oestradiol benzoate on the pituitary-thyroid axis of male and female rats. Acta Endocrinologica. 1983; 102: 386-91.

34. D'Angelo SA, Fisher JS. Influence of estrogen on the pituitary-thyroid system of the female rat: mechanisms and loci of action. Endocrinology. $1969 ; 84: 117-22$

35. D'Angelo SA. Simultaneous effects of estradiol on TSH secretion and adrenocortical function in male and female rats. Endocrinology. $1968 ; 82: 1035-41$

36. Bruhn TO, Jackson IM. Abnormalities of the thyroid hormone negative feedback regulation of TSH secretion in spontaneously hypertensive rats. Regul Pept. 1992;38:221-30.

37. Banu SK, Govindarajulu P, Aruldhas MM Testosterone and estradiol differentially regulate TSH-induced thyrocyte proliferation in immature and adult rats. Steroids. 2002;67:573-9.

38. Moreira RM, Lisboa PC, Curty FH, Pazos-Moura CC. Dose-dependent effects of 17-ß-estradiol on pituitary thyrotropin content and secretion in vitro. Braz J Med Biol Res. 1997;30:1129-34. 